\title{
ШТРАФНИКИ НА ФРОНТАХ ВЕЛИКОЙ ОТЕЧЕСТВЕННОЙ ВОЙНЫ: МИФЫ И РЕАЛЬНОСТЬ
}

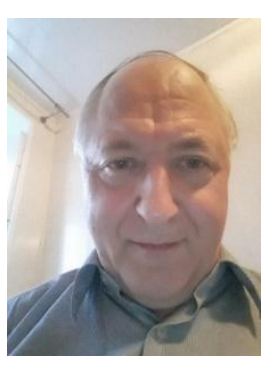

Б.П. Дементьев, доктор исторических наук, профессор Пермского государственного наиионального исследовательского университета, Пермь

b-demen@yandex.ru

Аннотация. Анализируется история и практика штрафных подразделений в мировой истории и истории Второй мировой и Великой Отечественной войны. Рассматриваются следующие вопросы: первые документально подтвержденные факты о созданиях штрафных подразделений в мировой истории; приказ № 227 от 28 июля 1942 г.; создание штрафных рот и штрафных батальонов, комплектование, состав, вооружение, участие в боевых действиях, мифы и реальность о штрафных подразделениях.

Ключевые слова: история, война, штрафные роты и батальоны, мифы и реальность.

Boris Dementiev, doctor of historical Sciences, professor of Perm state national research university, Perm b-demen@yandex.ru

\section{PENALTY ON FRONTS OF THE GREAT PATRIOTIC WAR: MYTHS AND REALITY}

\begin{abstract}
In article is analyzed history and practice of the penalty subdivisions in world history and histories Second world and Great Patriotic war. They are Considered following questions: the first documentary confirmed facts about making the penalty subdivisions in world history; the order 227 from July 28 1942; creation penalty mouth and penal battalions, комплекто-
\end{abstract}


вание, composition, arms, participation in combat action, myths and reality about penalty subdivisions. reality.

Keywords: history, war, penalty companies and battalions, myths and

В фильмах, в художественной литературе, даже в значительной части научных статей и монографий создание штрафных подразделений связывается с приказом Наркомата обороны СССР № 227 от 28 июля 1942 г.

На самом деле первые (документально подтвержденные) штрафные подразделения появляются уже 1804 г. в британской армии в Сенегале. Затем - в 1811 г. в армии Наполеона. Кстати, они использовались Наполеоном в войне с Россией в 1812 г. И уже через два месяца от этих формирований мало что осталось. Далее практика штрафных подразделений продолжается во время Первой мировой войны, особенно широко это происходит во французской армии. Появляются в сентябре 1917 г. они и в российской армии, но в связи с нараставшим революционным кризисом в боевых действиях не участвуют [1, с. 43-47].

В 1936 г. штрафные подразделения появляются в германской армии. После начала Второй мировой войны в Германии в 1940 г. они уже применяются не только в сухопутных частях, но и в авиации и на флоте [2, с. 273-274].

В начале Великой Отечественной войны в Красной армии толчок идее возникновения штрафных батальонов дали первые месяцы войны. В условиях тотального отступления Красной армии частым явлением стали случаи дезертирства или проявления трусости, на что командиры нередко реагировали наиболее жестким образом - расстрелом. Чтобы не доводить до расстрела, начинают создаваться первые штрафные подразделения. Так, в августе 1941 г. генерал Василевский выпустил распоряжение, согласно которому в штрафные танковые роты сводился личный состав, уличенный в саботаже и вредительстве, а в штрафные пехотные роты следовало отправлять «безнадежных, злостных шкурников из танкистов» [3, с. 75].

Штрафные батальоны, как и штрафные роты, начали появляться в 1942 г. В общевойсковых армиях должны были создать до 5 штрафных рот, в каждом фронте - до 3 штрафных батальонов $[4$, c. 72$]$. 
За что можно было попасть в штрафники? За самовольное покидание позиции, за превышение служебных полномочий, за хищение, за оскорбление старшего по званию, по собственной инициативе при желании попасть из заключения в действующую армию.

Как комплектовались? Штрафные батальоны - только из офицеров. Штрафные роты - из рядового и сержантского состава. В качестве альтернативной меры наказания допускалось направление в штрафные роты гражданских лиц, осуждённых судом за совершение нетяжких и средней тяжести общеуголовных преступлений. Лица, осуждённые за тяжкие и государственные преступления, отбывали наказания в местах лишения свободы. Лица, осужденные по политическим статьям, в штрафные подразделения не отправлялись. В то же время имелись отдельные случаи направления в штрафные подразделения «политических» заключённых (в частности, в 1942 г. в 45-ю штрафную роту был направлен осуждённый в 1941 г. на 5 лет лагерей по 58-й статье Владимир Карпов, ставший впоследствии Героем Советского Союза и известным писателем) [5, с. 3].

Личный состав штрафбатов и штрафрот делился на переменный и постоянный. Переменный состав представлял собою непосредственно штрафников, находившихся в подразделении временно до отбытия срока наказания (до трёх месяцев), перевода в обычную часть за проявленное личное мужество, по ранению или до гибели. Постоянным составом являлись командиры подразделений от взвода и выше, назначавшиеся из числа кадровых офицеров, политработники, штабные работники (связисты, писари и др.) и медицинский персонал. Штат штрафного батальона насчитывал 800 человек, штрафной роты - 200 [6, с. 224].

Как вооружались? Мифология (в фильмах и т.п. продукции) говорит об «одной винтовке на троих» или чуть ли не о черенках от лопат. Конечно же, этого быть не могло. Учитывая, что штрафные части бросали на самые тяжелые участки фронта, их нельзя было не снабжать достаточным количеством оружия и боеприпасов.

Более того, штрафников зачастую наделяли самым передовым оружием, например противотанковыми ружьями системы Симонова или 7,62-миллиметровыми пулеметами системы Горюнова, которые еще даже не использовались в гвардейских частях [7, с. 122].

Была ли мотивация у штрафных подразделений? В штрафных батальонах мотивация была запредельной. Желание вернуть офицерские погоны, реабилитировать свое имя и вернуться на за- 
нимаемую ранее должность и так были отличной мотивацией. Штурмовые батальоны воевали дерзко и смело.

В фильмах, в художественной литературе нередко показывается, что у штрафных рот (где значительную часть состава представляли уголовники) не было мотивации. Отсиживались и не геройствовали. Это не совсем так. Забывается, что были условия освобождения из штрафных подразделений. Основаниями для освобождения лиц, отбывающих наказание в штрафных войсковых подразделениях, являлись:

1. Отбытие срока наказания (не более трёх месяцев). Осуждённые на 10 лет - 3 месяца, от 5 до 8 лет - 2 месяца, до 5 лет месяц.

2. Для штрафных эскадрилий - число и итоги боевых вылетов.

3. Получение военнослужащим, отбывающим наказание, средней тяжести или тяжёлого ранения, требовавшего госпитализации.

4. Досрочно решением военного совета армии по ходатайству командира штрафного войскового подразделения в виде поощрения в отношении военнослужащих, проявивших исключительное мужество и храбрость [8, с. 77].

Потери личного состава. Вероятность погибнуть в штрафбатах была на порядок выше, чем в обычных частях РККА. Смертность была в среднем в 3-4 раза выше, чем в линейных частях [9, c. 118].

Сколько было штрафных батальонов и штрафных рот? За всю войну (то есть не одновременно) на всех фронтах в годы Великой Отечественной войны в Вооруженных силах СССР было сформировано 65 отдельных штрафных батальонов (ошб) и 1048 отдельных штрафных рот (ошр).

За все годы Великой Отечественной войны через штрафные части прошло по некоторым данным 427910 человек. Если учесть, что за всю войну через Вооружённые силы СССР прошло 34476700 человек, то доля бойцов и командиров (офицеров) РККА, прошедших через штрафные части за весь период Великой Отечественной войны, составляет примерно 1,24 \% [10, с. 81].

\section{Список литературы}

1. Донских С.В. Штрафные батальоны Наполеона в войне 1812 года // Война 1812 года. - Витебск: Кн. изд., 2012. - 164 с. 
2. Пересвет А. По ту сторону прицела, по эту сторону души // Хенс В., Пересвет А. По другую сторону войны. - М.: Интерэксперт, 2005. $-275 \mathrm{c}$.

3. Рубцов Ю. Штрафники Великой Отечественной войны. В жизни и на экране. - М.: Вече, 2013. -432 с.

4. Орлов А. Штрафбат. Приказано уничтожить. - М.: АСТ, 2012. $-152 \mathrm{c}$.

5. Гавриленко А. «Маршальский жезл» Владимира Карпова // Красная звезда. - 2006. - 6 мая.

6. Телицын В. Мифы о штрафбатах. - М.: Эксмо, 2010. - 255 с.

7. Громов А. Правда о штрафбатах и заградотрядах во Второй мировой. - Белгород: Эксмо, 2010. - $416 \mathrm{c}$.

8. Пыхалов И. Штрафбаты по обе стороны фронта. - М.: Эксмо, 2007. - 244 с.

9. Сукнев М. Записки командира штрафбата. - М.: Центрполиграф, 2006. -264 с. $225 \mathrm{c}$.

10. Пыльцын А. Правда о штрафбатах. - М.: Эксмо, 2007. - 